\title{
The evolution of the Romanian insurance market after 2000
}

\section{Mihaela Simionescu}

Institute for Economic Forecasting of the Romanian Academy,

Centre for Migration Studies in Prague Business School,

Global Labor Organization (GLO),

050711, Bucharest - Romania, Casa Academiei, Calea 13 Septembrie nr.13, sector 5

Habilitated Doctor

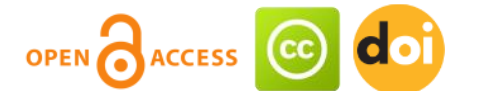

Article history:

Received: January 09, 2019

1st Revision: January 21,

2019

Accepted: April 06, 2019

\section{JEL classification:} G22

DOI:

10.14254/jems.2019.4-1.2

\begin{abstract}
Considering the qualitative changes in the legislative framework, the Romania's entrance into the European Union and the recent global economic crisis, the Romanian insurance market is analyzed by considering ten representative insurance companies. A panel autoregressive-model (PVAR) model for the ten insurance companies was constructed for the period 2004-2017. This model suggested that the indemnities paid by the insurance companies negatively affected the liquidity but with a lag of two periods after changes in indemnities. Granger causality test indicated a causal relationship from indemnities variation to gross written premium in the same period. Almost $27 \%$ of the variation in indemnities rate is explained by a shock in the rate of gross written premium.
\end{abstract}

Keywords: insurance market, insurance company, global economic and financial crisis, PVAR model, Granger causality.

\section{Introduction}

Insurance companies play an important role in the national economy that is deeply affected by uncertainties generated by the international environment, but also by disturbances specific to the local economy.

In this paper, ten Romanian insurance companies were analyzed, the selection of the firms being made after the continuity of their activity and data availability. Excepting Asito Kapital and Carpatica, all the other firms kept their names, even if structural changes were observed for many companies. The insurance companies are different according to size and turnover, but they have some important common features: long-lived companies with credibility and prestige in the domain, have decisive influence on the Romanian insurance market, influence the education of the population on insurance. 
The considered period (2004-2017) covers important events that influenced the companies' indicators: Romania's integration in the EU (since the $1^{\text {st }}$ of January 2007), the global economic and financial crisis (2008-2010), the introduction of the Solvency II macro-prudential supervisory system (since the $1^{\text {st }}$ of January 2016). Vienna Insurance Group (VIG) dominates the insurance markets in the Central and Eastern Europe, holding three of the ten analyzed insurance companies: BCR Asigurări de Viață - for life insurance activities, OMNIASIG - for non-life insurance segment, and ASIROM - for both insurance segments.

\section{Romanian insurance market after 2004}

After 2000, the Romanian insurance market experienced many qualitative transformations as a consequence of the application of Law 32/2000. The law was designed to regulate the supervision of the insurance market by founding the Insurance Supervisory Commission (Teodorescu, 2010). This Commission was an independent body that was subordinated to Parliament. It was subject to the EU rules related to authorization of insurance companies, verification of the achievement of mandatory criteria for the establishment and report of active and technical reserves, calculation and report of the solvency margin, the creation of database and IT systems for insurance market supervision. Insurance Supervisory Commission provided annual reports on the evolution of the Romanian insurance market, growing the transparency of insurance activities. Moreover, the law given in 2000 was amended by the Law 403/2004 in order to take into account all the provisions of the European directives on the classification of insurance. This law established the legislative framework in case of bankruptcy of insurance companies and their financial recovery, in accordance with the EU directives (Ducháčková \& Daňhel, 2010; 2015).

Beside legislative changes, two important influenced the Romanian insurance market after 2004: Romania's accession to the EU and the recent global economic crisis. The Romania's integration in the European Union on the $1^{\text {st }}$ of January 2007 brought important transformations of insurance market, that achieved a considerable consolidation and maturity (Hrabalova et al., 2017; De Grauwe, 2014; Zweifel \& Eisen, 2012; Pavlat \& Kubicek, 2010). More foreign-owned insurance companies appeared in Romania after 2007. The premium rates for compulsory third-party liability insurance were liberalized. Progress was achieved in the process of harmonization of national legislation with the EU one. Supervisory tools for insurance and consumer protection were improved. The solvency criteria for insurers according to European standards, the requirements related to correlation between acquisition costs and the structure of the portfolio and the damage were tightened (Muzakova \& Stibranyiova, 2014; Alexandru \& Armeanu, 2007).

In the case of Romanian insurance market, Ioncica et al. (2012) showed a significant discrepancy between the high potential demand for insurance and the low effective demand caused by low education in this domain. Other empirical evidence indicated no strong correlation between insurance penetration or insurance density and economic growth in Romana in the period 19972012 (Cristea et al., 2014).

Analysing the structure of the insurance market in the new EU member states (Bulgaria, Romania, Czech Republic, Estonia, Poland, Slovenia, Slovakia, Hungary) in the period 2000-2010, Kramaric and Kitic (2012) evaluated the concentration of insurance companies. The financial performance of the Romanian insurance market is influenced by few factors revelled by Burca and Batrânca (2014) in a panel data analysis for the period 2008-2012: gross written premiums growth, financial leverage, company size, solvency margin, subscribed risk, risk retention ratio.

In 2004, the ten companies held almost 55\% of the gross written premiums from the Romanian insurance market, the leader being Allianz Tiriac with $21 \%$ as the local insurance market. ABC Asigurări was the company with the lowest share $(0.1 \%)$, according to data provided by the Romanian Financial Supervisory Authority. Since 2004 till 2017, these companies experienced continuity and stability, because they registered increase in the share of gross written premiums.

ASIROM is the oldest insurance company, being established on the $1^{\text {st }}$ of January 1991. It covers both segments: life and non-life insurance. Along the time, this firm developed a powerful network of branch offices in the entire country.

Allianz Țiriac Asigurări S.A. was founded in 1994 under the name Asigurări Ion Ţiriac. In 2000, the company sold more than half of the shares to German group Allianz. Most of the earnings come from non-life policy sales, only a small part being due to life insurance services. Actually, this company was the leader since 2004 till present on the non-life insurance segment.

ABC Asigurări - Reasigurări was established in 1997, having entire Romanian share capital. It diversified its shareholding, because in 2000, the Romanian Insurance and Reinsurance 
Activity Supervisory Office requested the company's capital growth. Since 2005, the company has been authorized to provide compulsory civil liability insurance services for car owners.

Carpatica Asig, established in 1996, had initially the name ASA Asigurari Atlassib, that was changed in 2004. The company developed its strategy, mostly after 2009, by promoting the compulsory RCA insurances. However, in 2015 it did not meet the requirements of Solvency I. The company did not solve the financial issues by attracting investors in the period 2015-2016. The Council of the Financial Supervisory Authority initiated Carpatica's bankruptcy procedure and the company's operating license was withdrawn in 2018.

ASITO KAPITAL S.A. was found initially as Lukoil Asito in 1998, to support the Romanian businesses and to secure the assets of the Lukoil oil group in Romania. In 2011, 99\% of the company was bought by the Moldavian company Moldasig that changed the name to Asito Kapital.

City Insurance is an insurance-reinsurance company established in 1998, having entire Romanian shareholding. It came up with products from the general insurance category. In 2011, the firm adopted an online insurance sales portal known as CitySmart.ro and in 2017, City Insurance became leader on the Romanian insurance market for non-life insurance and RCA segment.

GARANTA ASIGURĂRI is a branch in Romania of the Ethniki Hellenic General Insurance Company from Greece since 1997. It provides life and non-life insurance services. Garanta paid an indemnity of 5 million Euro after the fire from Balotesti.

Generali Romania Reinsurance Insurance appeared on Romanian insurance market in 1993, providing life and non-life insurance services.

Uniqa Asigurări was the first insurance company in Romania having entire private capital (known as Unita) and offering life insurance non-life insurance products. In 2002, Wiener Städtische from Austria became the main shareholder. In 2008, UNIQA Insurance Group acquired all the UNIQA Asigurări shares.

Omniasig VIG is part of Vienna Insurance Group, being the largest company of the Austrian group in Romanian portfolio. It provides life and non-life insurance products. This company merged with BCR Asigurari in 2012, increasing its capital by 158\%. In 2015, Omniasig received two important awards: "Flexibility in Negotiation and Bidding" Award at the UNSICAR Awards Gala and "Best in Non-Life in 20 Years" Excellence Award offered by the Financial Market.

\section{A Panel vector-autoregressive (PVAR) model for the sample of insurance companies}

A PVAR model is employed to assess the relationships between economic indicators of these ten insurance companies taking into account the late impact of some variables. In general, vectorautoregressive models (VAR models) are used to study the dynamic relationships between interdependent actives at microeconomic, sectoral or regional level.

The PVAR model of order 3 is built for the following indicators in case of the ten insurance companies for the period 2004-2017: liquidities, index of change for paid indemnities and index of change for gross written premium.

If $y_{i t}$ includes $\mathrm{G}$ variabiles, where $\mathrm{i}(\mathrm{i}=1, \ldots, \mathrm{N})$ is the index for companies at time $t(\mathrm{t}=1, \ldots, \mathrm{T})$ and $Y_{t}=\left(y_{1 t}^{\prime}, \ldots, y_{N t}^{\prime}\right)^{\prime}$. For an insurance company $i$, the PVAR model is built as:

$$
y_{i t}=A_{1 i} Y_{t-1}+\cdots+A_{P i} Y_{t-P}+e_{i t}
$$

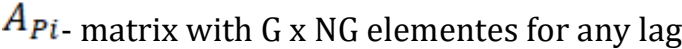

$\mathrm{p}-\operatorname{lag}(\mathrm{p}=1, \ldots, \mathrm{P})$

$e_{i t}$ - erorrs uncorrelated in time following a normal distribution $\left(\mathrm{N}\left(0, \Sigma_{i i}\right)\right)$

$\Sigma_{i i}$ - variance-covariance matrix (G x G elements)

$\Sigma_{i j}=\operatorname{cov}\left(e_{i t}, e_{j t}\right)=E\left(e_{i t}, e_{j t}\right)$ is variance-covariance matrix between VAR errors for companies i and j

This specification for the unrestricted PVAR model at optimal lag 3 is:

$$
y_{i t}=A_{1 i} Y_{t-1}+A_{2 i} Y_{t-2}+A_{3 i} Y_{t-3}+e_{i t}
$$

The panel VAR model is built on stationary data. At a significance level of 5\%, the liquidities (L) data series is stationary according to the Im-Pesaran-Shin test. The data series for indemnities and incomes from gross written premiums are not stationary at a significance level of 5\%, but the series converted by calculating the indemnity index (variable labeled I) and the gross written premium income (variable P) are stationary.

Following the application of Granger's causality test on stationary data (Table 1), it was concluded that there is only one causal relationship from the variation in indemnities to the change 
in gross written premium income. In other words, if the variation from year to year in paid indemnities has changed, then the change in gross written premium income changes. If the company paid a higher value for benefits this year than the previous year, then it will also increase the amount of gross written premiums so that it can cover any losses if the next year will pay more than expected.

\begin{tabular}{lcc}
\begin{tabular}{l} 
Table 1: Granger test for causal relationships between stationary data variables \\
\hline Hypothesis
\end{tabular} & Statistics & Probability \\
\hline $\begin{array}{l}\text { Variation in indemnities income is not a } \\
\text { cause for liquidity }\end{array}$ & 0.08 & 0.93 \\
\hline $\begin{array}{l}\text { Variation in gross written premium income is } \\
\text { not a cause for liquidity }\end{array}$ & 0.097 & 0.9 \\
\hline $\begin{array}{l}\text { Liquidities are not a cause for changes in } \\
\text { indemnities }\end{array}$ & 0.13 & 0.98 \\
\hline $\begin{array}{l}\text { The variation in gross written premium } \\
\text { income is not a cause of change in } \\
\text { indemnities }\end{array}$ & 0.33 & 0.88 \\
\hline $\begin{array}{l}\text { Liquidities are not a cause for the change in } \\
\text { gross written premium income }\end{array}$ & 0.13 & $\mathbf{0 . 0 0}$ \\
\hline $\begin{array}{l}\text { The variation in indemnities is not a cause for } \\
\text { the change in gross written premium income }\end{array}$ & 877.53 & \\
\hline
\end{tabular}

\section{Source: own computations}

According to the optimal lag selection criteria, at a significance level of $5 \%$, the best lag is equal to 3.

The results of the root of the characteristic polynomial are presented in Table 2.

Table 2: Roots of characteristic polynomial

\begin{tabular}{cc}
\hline Root & Absolute value \\
\hline $0.666506-0.040304 \mathrm{i}$ & 0.667723 \\
$0.666506+0.040304 \mathrm{i}$ & 0.667723 \\
$-0.255691-0.427713 \mathrm{i}$ & 0.498313 \\
$-0.255691+0.427713 \mathrm{i}$ & 0.498313 \\
-0.372691 & 0.372691 \\
$0.269341-0.250582 \mathrm{i}$ & 0.367880 \\
$0.269341+0.250582 \mathrm{i}$ & 0.367880 \\
$-0.089236-0.312800 \mathrm{i}$ & 0.325280 \\
$-0.089236+0.312800 \mathrm{i}$ & 0.325280 \\
\hline
\end{tabular}

Source: own computations

The model complies with the conditions of stability, the roots of the characteristic polynomial being within the unit circle.

The results of optimal lag selection are shown in Table 3.

\begin{tabular}{ccccccc}
\multicolumn{7}{l}{ Table 3: The optimal lag selection criteria for the panel VAR model } \\
\hline Lag & LogL & LR & FPE & AIC & SC & HQ \\
\hline 0 & -1804.99 & NA & $2.49 \mathrm{e}+19$ & 53.18 & 53.27 & 53.22 \\
1 & -1782.72 & 41.92 & $1.69 \mathrm{e}+19$ & 52.79 & 53.18 & 52.95 \\
2 & -1776.52 & 11.12 & $1.84 \mathrm{e}+19$ & 52.87 & 53.56 & 53.14 \\
3 & -1672.95 & $176.69^{*}$ & $1.14 \mathrm{e}^{*}+18^{*}$ & $50.09^{*}$ & $51.06^{*}$ & $50.48^{*}$ \\
\hline
\end{tabular}

* indicates the lag selected by that criterion at a significance level of $5 \%$

LR: modified likelihood ratio test statistic

FPE: final prediction error

AIC: Akaike Information Criterion

SC: The Schwarz Information Criterion

HQ: Hannan-Quinn Information Criterion

The following equations were obtained:

$\mathrm{L}=0.28 * \mathrm{~L}(-1)+0.067 * \mathrm{~L}(-2)+0.17 * \mathrm{~L}(-3)+449548425.44 * \mathrm{I}(-1)-11232641.98 * \mathrm{I}(-2)-$ $5673030.89 * \mathrm{I}(-3)-40832837.96 * \mathrm{P}(-1)-53067603.12 * \mathrm{P}(-2)-33195938.22 * \mathrm{P}(-3)+528448056.46$ 
$\mathrm{I}=7.39 \mathrm{e}-11 * \mathrm{~L}(-1)-4.45 \mathrm{e}-11 * \mathrm{~L}(-2)-1.97 \mathrm{e}-11 * \mathrm{~L}(-3)+0.57 * \mathrm{I}(-1)-0.02 * \mathrm{I}(-2)+0.011 * \mathrm{I}(-3)+$ $0.0013 * \mathrm{P}(-1)+0.002 * \mathrm{P}(-2)+0.018 * \mathrm{P}(-3)+0.46$

$\mathrm{P}=6.14 \mathrm{e}-11 * \mathrm{~L}(-1)-2.92 \mathrm{e}-11 * \mathrm{~L}(-2)-1.56 \mathrm{e}-11 * \mathrm{~L}(-3)+0.027 * \mathrm{I}(-1)-0.009 * \mathrm{I}(-2)+0.25 * \mathrm{I}(-3)-$ $0.04 * \mathrm{P}(-1)+0.03 * \mathrm{P}(-2)-0.004 * \mathrm{P}(-3)+0.79$

As can be seen from the above equations, indemnities paid by insurance companies negatively affect liquidity only after two periods. Moreover, the gross written premium income is directed towards the payment of indemnities rather than the conversion to liquidity. Liquidities are also used to pay indemnities.

For this panel VAR model, the errors are homoscedastic (the probability associated with the homoscedasticity test statistic is 0.06 , greater than 0.05 ) at a significance threshold of $5 \%$. Error distribution is not normal and there is a slight correlation of errors in the first lag, but which disappears over time. Liquidity responses to a shock in variables are presented in Table 4.

\begin{tabular}{cccc}
\hline Table 4: Response of liquidities to one shock in variables & \\
\hline Period & $\mathbf{L}$ & $\mathbf{I}$ & $\mathbf{P}$ \\
\hline 1 & $2.8 \mathrm{E}+09$ & 0.000000 & 0.000000 \\
2 & $7.5 \mathrm{E}+08$ & $2.50 \mathrm{E}+08$ & -21830121 \\
3 & $4.8 \mathrm{E}+08$ & $1.96 \mathrm{E}+08$ & -33175233 \\
4 & $6.6 \mathrm{E}+08$ & $1.42 \mathrm{E}+08$ & -27859614 \\
5 & $3.2 \mathrm{E}+08$ & $1.38 \mathrm{E}+08$ & -9948742. \\
6 & $2.1 \mathrm{E}+08$ & 96697444 & -8761963. \\
7 & $1.8 \mathrm{E}+08$ & 65033486 & -6115756. \\
8 & $1.07 \mathrm{E}+08$ & 51045092 & -3088512. \\
9 & 72132778 & 36094334 & -2288550. \\
10 & 53252603 & 25147028 & -1581077. \\
\hline
\end{tabular}

Source: own computations

One year after a shock in indemnities variation and in the change in gross written premium income, liquidity does not change. In the following periods, liquidity responds positively to the shock of changing indemnities, but they respond negatively to the shock of changing gross written premiums. Therefore, the indemnities tend to decrease, but also due to the fall in gross written premiums. Table 5.

The responses to the modification of indemnities to a shock in the variables are presented in

Table 5: The response of indemnities variation to a shock in variables

\begin{tabular}{cccc}
\hline Period & $\mathrm{L}$ & $\mathrm{I}$ & $\mathrm{P}$ \\
\hline 1 & -0.033 & 0.584 & 0.00 \\
2 & 0.186 & 0.335 & 0.0007 \\
3 & 0.04 & 0.201 & $8.4 \mathrm{E}-05$ \\
4 & -0.035 & 0.12 & 0.008 \\
5 & -0.003 & 0.07 & 0.004 \\
6 & -0.016 & 0.04 & 0.004 \\
7 & -0.021 & 0.02 & 0.002 \\
8 & -0.013 & 0.013 & 0.0015 \\
9 & -0.012 & 0.008 & 0.001 \\
10 & -0.01 & 0.004 & 0.0007 \\
\hline
\end{tabular}

Source: own computations

One year after a shock in liquidity, the change in indemnities responds negatively, so that after four and longer periods the response will stabilize to a negative value, but close to 0 . At a shock in indemnities variation, this variable responds positively, the influence decreasing gradually to 0 . On a shock in the variation of the gross written premium income, after a period the income variation does not change, the subsequent response being positive but close to 0 . Therefore, the indemnities paid do not change too much in the case of shocks in the variables analyzed.

The responses of the variation of the income from gross written premiums to a shock in variables are presented in Table 6. 


\begin{tabular}{llll}
\multicolumn{4}{l}{ Table 6: Response to the change in gross written premium income to a shock in variables } \\
\begin{tabular}{llll} 
Period & $\mathrm{L}$ & $\mathrm{I}$ & $\mathrm{P}$ \\
\hline 1 & -0.056 & 0.32 & 0.53 \\
2 & 0.172 & 0.003 & -0.02 \\
3 & -0.038 & 0.03 & 0.017 \\
4 & -0.038 & 0.15 & -0.005 \\
5 & 0.059 & 0.08 & 0.0008 \\
6 & -0.0004 & 0.05 & 0.0005 \\
7 & -0.013 & 0.03 & 0.0022 \\
8 & -0.0009 & 0.02 & 0.001 \\
9 & -0.006 & 0.01 & 0.001 \\
10 & -0.006 & 0.006 & 0.0006 \\
\hline
\end{tabular}
\end{tabular}

\section{Source: own computations}

One year after a shock in cash, the variation in gross written premium income is negative, so that from the third and even longer times the response will stabilize to a negative value, but close to 0 . In case of a shock in indemnities variation, the variation in the gross written premium income is positive. In case of a shock in the variation in gross written premium income, after a period, the income variation responds positively, the answer being close to 0 .

The variance decomposition of the PVAR model is shown graphically in Figure 1. It is noted that a shock in the growth rate of indemnities explains after a period only $3.2 \%$ of the variation in a company's liquidity. The biggest influence is manifested after two periods of shock, when $7.3 \%$ of the fluctuation of the liquidity is explained by changes in the indemnity rate. One year after shock, there is no change in the rate of gross written premium income.

\section{Figure 1: Variance decomposition}

Variance Decomposition of CASA

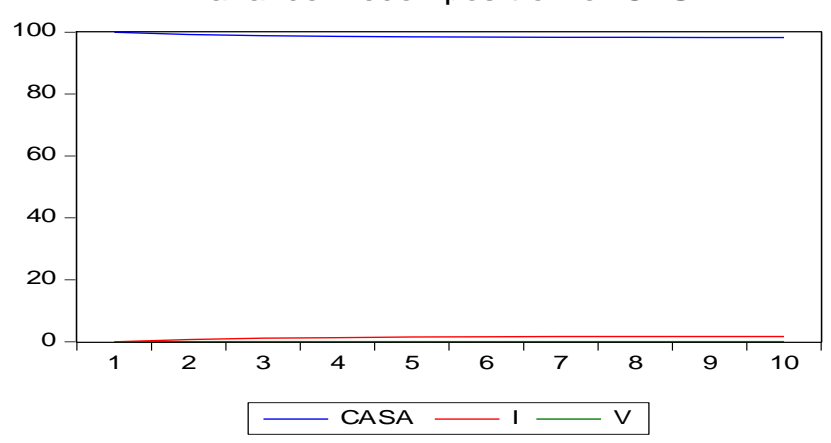

Variance Decomposition of I

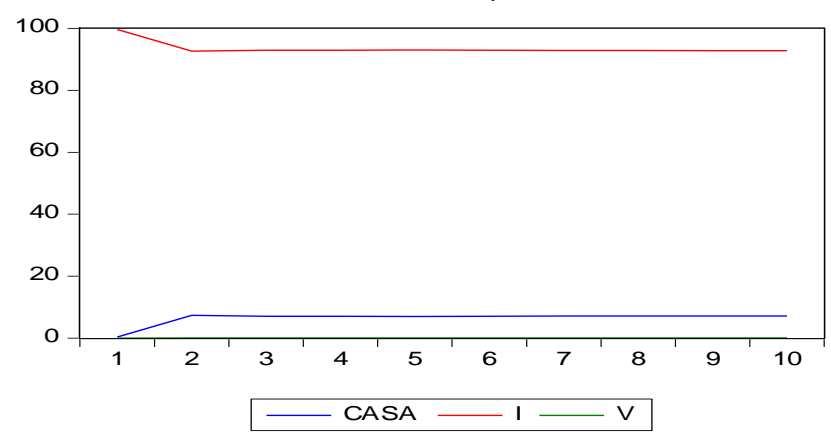

Variance Decomposition of $\mathrm{V}$

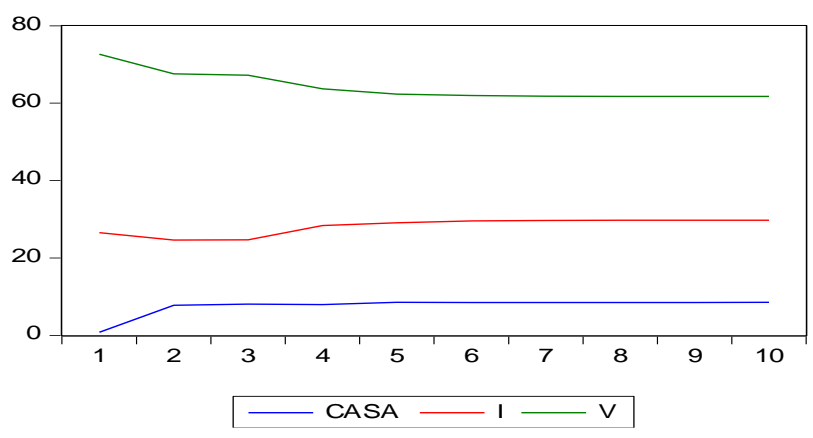


Moreover, $26.5 \%$ of the indemnities variation is explained by a shock in the rate of gross written premium income after one year. Influence on liquidity is quite low. $0.8 \%$ of the fluctuation in liquidity is explained by changes in the rate of gross written premium income. Only two years later, a shock in the gross written premium income ratio explains $7.7 \%$ of the liquidity variance, the influence slightly increasing over time and reaching 8.5\% at lag 10.

\section{Conclusions}

Insurance companies that are representative for the Romanian insurance market experienced various intermediate development phases, being supported by public institutions, in their efforts to harmonize the national framework with the European directives. The European legislative promotions follow the long-term goal of ensuring a climate of confidence in the insurance sector among the population.

This paper considered ten insurance companies from Romania that cover about $80 \%$ of the market. The recent global economic and financial crisis started in 2008 determined significant changes also on the insurance market like bankruptcy (ASIROM) or merger (ALLIANZ-ȚIRIAC).

A panel autoregressive-model (PVAR) model for the ten insurance companies in the period 2004-2016 suggested that the indemnities paid by the insurance companies negatively affected the liquidity only after two periods, the gross written premium income is directed towards the payment of the indemnities and not to the conversion into liquidities, and liquidities are also used for the payment of the indemnities. A shock in the indemnities rate explains after one period only $3.18 \%$ from the variation in companies' liquidities while after two periods only $7.31 \% .26 .54 \%$ of the variation in indemnities rate is explained by a shock in the rate of gross written premium. Granger causality test indicated a causal relationship from indemnities variation to gross written premium in the same period.

\section{Appendix A. Supplementary material}

Supplementary data associated with this article can be found, in the online version, at https://doi.org/10.14254/jems.2019.4-1.1

\section{Funding}

The authors received no direct funding for this research.

\section{Citation information}

Simionescu, M. (2019). The evolution of the Romanian insurance market after 2000. Economics, Management and Sustainability, 4(1), 21-28. doi:10.14254/jems.2019.4-1.2

\section{References}

Alexandru, F., \& Armeanu, D. (2007) Asigurări de bunuri și persoane, Editura Economică, București.

Burca, A. M., \& Batrinca, G. (2014). The determinants of financial performance in the Romanian insurance market. International Journal of Academic Research in Accounting, Finance and Management Sciences, 4(1), 299-308.

Cristea, M., Marcu, N., \& Cârstina, S. (2014). The relationship between insurance and economic growth in Romania compared to the main results in Europe-a theoretical and empirical analysis. Procedia Economics and Finance, 8, 226-235.

De Grauwe, P. (2014). Macroeconomic policies in the Eurozone since the sovereign debt crisis. $K U$ Leuven, Euroforum.

Ducháčková, E., \& Daňhel, J. (2010). Teorie pojistných trhů. Professional Publishing.

Ducháčková, E., \& Daňhel, J. (2015). Proceedings of the $7^{\text {th }}$ International Conference Financial markets within the globalization of world economy. Praha: Eupress.

Hrabalova, E., Vavrova, E., \& Hampel, D. (2017). New approaches to regulating insurance markets in the European Union in the aftermath of the financial crisis y (No. 2017-72). Mendel University in Brno, Faculty of Business and Economics.

Hull, J. (2015). Risk management and financial institutions. 4th edition: John Wiley. 
Ioncică, M., Petrescu, E. C., Ioncică, D., \& Constantinescu, M. (2012). The role of education on consumer behavior on the insurance market. Procedia-Social and Behavioral Sciences, 46, 4154-4158.

Kramaric, T. P., \& Kitic, M. (2012). Comparative analysis of concentration in insurance markets in new EU member states. Romania, 1, 92-84.

Muzakova, K., \& Stibranyiova, L. (2014). European Insurance Markets: Size and Trends in Regulatory Environment in the Context of Its Complexity. Journal of Modern Accounting and Auditing, 10(8), 865-877.

Pavlat, V., \& Kubicek, A. (2010). Regulace a dohled nad financnimi trhy. Praha: VSFS.

Teodorescu, S. (2010) Fundamentele asigurărilor, Editura Bren, București.

Zweifel, P., \& Eisen, R. (2012). Insurance Economics. Berlin: Springer Verlag.

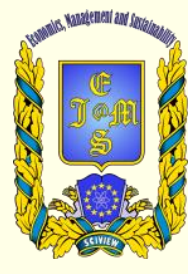

(c) 2016-2019, Economics, Management and Sustainability. All rights reserved.

This open access article is distributed under a Creative Commons Attribution (CC-BY) 4.0 license.

You are free to:

Share - copy and redistribute the material in any medium or format Adapt - remix, transform, and build upon the material for any purpose, even commercially.

The licensor cannot revoke these freedoms as long as you follow the license terms.

Under the following terms:

Attribution - You must give appropriate credit, provide a link to the license, and indicate if changes were made.

You may do so in any reasonable manner, but not in any way that suggests the licensor endorses you or your use.

No additional restrictions

You may not apply legal terms or technological measures that legally restrict others from doing anything the license permits.

Economics, Management and Sustainability (ISSN: 2520-6303) is published by Scientific Publishing House "CSR", Poland, EU and Scientific Publishing House "SciView", Poland

Publishing with JEMS ensures:

- Immediate, universal access to your article on publication

- High visibility and discoverability via the JEMS website

- Rapid publication

- Guaranteed legacy preservation of your article

- Discounts and waivers for authors in developing regions

Submit your manuscript to a JEMS at http://jems.sciview.net or submit.jems@sciview.net

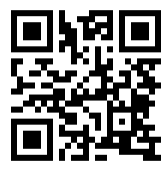

